\title{
A new synonym for Micropholis gardneriana (Sapotaceae) with complete description, anatomy and distribution notes
}

\author{
Angélica Cândida Ferreira ${ }^{1 *} \mathbb{D}^{-}$, Josiane Silva Araújo ${ }^{2} \mathbb{D}^{-}$Eduardo Bezerra de Almeida $\mathrm{Jr}^{3} \mathbb{\complement} \&$ \\ Carmen Silvia Zickel ${ }^{1}$ (1) \\ ${ }^{1}$ Universidade Federal Rural de Pernambuco, Departamento de Biologia, Pós-graduação em \\ Botânica, 52171-900, Recife, PE, Brasil \\ ${ }^{2}$ Universidade Estadual do Piaui, Departamento de Biologia, 64280-000, Campo Maior, PI, Brasil \\ ${ }^{3}$ Universidade Federal do Maranhão, Departamento de Biologia, 65080-805, São Luís, MA, Brasil \\ *Corresponding author: Angélica Cândida Ferreira, e-mail: angelicacferrer@gmail.com
}

Ferreira, A.C.; Araújo, J.S.; Almeida Jr., E.B.; Zickel, C.S. A new synonym for Micropholis gardneriana (Sapotaceae) with complete description, anatomy and distribution notes. Biota Neotropica. 20(1): e20190815. http://dx.doi.org/10.1590/1676-0611-BN-2019-0815

\begin{abstract}
In the present work, we synonymize Micropholis compta under M. gardneriana due to the overlap of morphoanatomical characters and the absence of distinctive attributes, verified during taxonomic and anatomical study of the genus Micropholis for Brazil. This study provides an updated description of M. gardneriana, including macro- and micro-morphological data, a distribution map, and comments on conservation status, ecological and taxonomy.
\end{abstract}

Keywords: Chrysophylloideae, leaf anatomy, Neotropics, South America, taxonomy.

\section{Um novo sinônimo para Micropholis gardneriana (Sapotaceae) com descrição completa, anatomia e notas de distribuição}

Resumo: No presente trabalho, sinonimizamos Micropholis compta sob M. gardneriana devido à sobreposição de caracteres morfoanatômicos e ausência de atributos distintivos, verificado durante estudo taxonômico e anatômico do gênero Micropholis para o Brasil. Este estudo fornece uma descrição atualizada de M. gardneriana, incluindo dados macro e micromorfológicos, um mapa de distribuição e comentários sobre status de conservação, ecologia e taxonomia.

Palavras-chave: Chrysophylloideae, anatomia foliar, Neotrópicos, América do Sul, taxonomia.

\section{Introduction}

Micropholis (Griseb.) Pierre, a Neotropical genus of Sapotaceae (Chrysophylloideae), currently comprises 38 species distributed across tropical and subtropical regions of Central and South America and the Caribbean islands, with the highest taxonomic diversity concentrated in humid tropical areas of Brazil (Pennington 1991; Swenson \& Anderberg 2005). Twenty-nine species of Micropholis occur in Brazil, predominantly in the Amazon Forest, where 26 taxa have been documented, 22 of which are endemic (Pennington 2006; Brazilian Flora 2020 under construction). Some species, though, occur in the Atlantic Forest, the Caatinga and the Cerrado (Pennington 2006; Brazilian Flora 2020 under construction). Micropholis represents an important component of lowland humid forest of South America the genus is ecological valuable and certain species are used by the lumber industry (Cruz \& Carvalho 2003; Reis et al. 2013; Raabe et al. 2017).

Representatives of Micropholis are characterized by their arboreal or shrubby habit, simple, alternate distichous or spiraled leaves, secondary and tertiary veins, often closely parallel, giving a striated appearance to the leaf lamina, unisexual and bisexual flowers, included or exserted stamens, lanceolate, subulate or petaloid staminodes, present or absent disc, (4-)5-locular ovary, bacoid fruits and laterally compressed seeds, with endosperm (Pennington 1990).

Pennington (1990) organized the genus into two sections. Micropholis sect. Micropholis comprised 29 species widely distributed throughout tropical America. The section is characterized by the presence of included stamens and corolla less than $10 \mathrm{~mm}$ long, with erect lobes. While $M$. sect. Exsertistamen comprises only nine species, distributed in the Guianas region that extends through the Brazilian Amazon to Peru; the species are characterized by exserted stamens and corolla over $10 \mathrm{~mm}$ long, with spaced or reflexed lobes.

The morphology of the corolla is important in delimiting the sections and species of Micropholis. However, the absence of flowers on many herbarium specimens possibly a consequence of the ephemeral nature of the flower of many Chrysophylloideae species (Terra-Araujo et al. 2012) impedes interspecific delimitation. Moreover, vegetatively, Micropholis can be easily confused with some species of the genera 
Chrysophyllum L., Diploon Cronquist and Pouteria Aubl., owing to similarities in their morphological characters.

The taxonomic delimitation of some species of Micropholis, such as M. compta and M. gardneriana, is not consistent across the taxonomic and floristic treatments (Pierre 1904; Pennington 1990; Souza et al. 2017). Despite being treated as distinct taxa, the current circumscriptions of these species describe overlapping diagnostic morphological characters, the differences between them being predominantly quantitative.

Quantitative and qualitative morphological variations, often observed in leaves, can be influenced by the different environmental conditions to which the plants are subjected (Bunger et al. 2015). Therefore, taxonomic and biosystematic studies must necessarily include specimens from several regions to ensure that taxonomic delimitations are precise, especially for widely distributed species (Landrum 1986).

During the elaboration of the taxonomic synopsis of the Brazilian species of Micropholis for this, we analyzed the protologues, the most recent taxonomic review of the species (Pennington 1990), the typus collections of the Micropholis species, and the anatomical material we concluded that $M$. compta Pierre exhibits morphological and anatomical characters that support its inclusion as a synonym of Micropholis gardneriana (A. DC.) Pierre.

\section{Materials and Methods}

The present study was based on an analysis of specimens from collections of the herbariums ASE, ALCB, BHCB, CEN, CENARGEN, CEPEC, CVRD, EUA, F, G, HUA, INPA, NY, MO, MBML, NL, PEURF, RB, UEC and US [acronyms according to Thiers (2019)]. The types were examined through images available on the website JSTOR Global plants (https://plants.jstor.org) (Ithaka 2019), and the protologues were consulted for all names.

Morphological attributes were obtained through direct observation of all specimens using a stereo microscope. To analyze the morphological variation between $M$. compta and M. gardneriana, we created a matrix containing the following vegetative and reproductive measurements for each species: leaf length, leaf width, petiole length, petiole width, flower length, sepal length, sepal width, and corolla length. Four of the seven measured characters were chosen because they were used by Pennington (1990) to establish the analyzed species (Table. 1). The measurements were taken with the aid of a digital pachymeter and a millimeter ruler. We conducted a descriptive statistical analysis of the absolute values of each character to obtain the measures of central tendency (average and median) and measures of dispersion (standard deviation, coefficient of variation, and amplitude); for this analysis, we used the software Excel (Microsoft Corporation 2009). Table 2 shows the variation in the measurements of each species. The terminology used to describe the morphological characters follows Beentje (2016). Information about the coloration of the fruits and seeds is based on dry material. Data related to habit, habitat, distribution and phenology were obtained through consulting herbarium labels and field notes.

The anatomical study was based on leaves of the specimens listed in the Table 3. Herborized leaf samples were submitted to the process of herborization reversal (Smith \& Smith 1942), dehydrated in ethyl series and stored in $70 \%$ ethanol. Cross and longitudinally sections of the leaf lamina (region middle) and the petiole, which were performed manually, were clarified in 50\% sodium hypochlorite and stained with basic fuchsin and astra blue. The semi-permanent laminas were mounted in glycerinated gelatin and sealed with colorless nail polish (Kraus \& Arduin 1997). Analysis and image capture were performed using a light microscope (model NO216T, New Optics, Ningbo, China) and an CMOS-0.5 Microscope Camera (Haryana, India). Images were captured using the software TCapture. The terminology used to describe the anatomical characters follows Howard (1979), Theobald et al. (1979) and Metcalfe \& Chalk (1983). The conservation status of the species was defined according to the criterion " $\mathrm{B}$ " proposed by the IUCN Red List, Version 3.1 (IUCN 2001), considering the extent of occurrence (EOO) and area of occupation (AOO), both obtained based on the geographic coordinates of the species locations, plotted on the GeoCAT (http://geocat.kew.org/) (Bachman et al. 2011). We created the distribution map in QGIS 2.18.28 software (Quantum GIS Development Team 2012) considering only confirmed occurrences.

\section{Results}

\section{Morphometric aspects}

The descriptive statistical data on the quantitative morphological characters are summarized in Table 2 . The character of flower length presented the highest coefficient of variation $(\mathrm{CV})$ for the analyzed taxa (M. gardneriana: 0.27 and M. compta: 0.65 ), followed by the character of sepal length $(0.41 ; 0.14)$. Among the vegetative characters, leaf length $(0.32 ; 0.49)$ and petiole length $(0.36 ; 0.47)$ presented the highest $\mathrm{CV}$ values for M. gardneriana and M. compta.

\section{Taxonomic treatment}

Micropholis gardneriana (A. DC.) Pierre, Not. Bot. 39. 1891. Type:-BRAZIL. Goiás, G. Gardner 3310 (holotype: G-DC; isotypes: G G00139918 [image!], K K000641491 [image!], K K000641492 [image!]). Figure 1A. Micropholis compta Pierre in Pierre \& Urban, Symb. Antill. 5: 125. 1904. Type: —BRAZIL. Rio de Janeiro: Glaziou 17691 (holotype: P P00648164 [image!]; isotypes, F F0072093F [image!]; G G00237370 [image!]). Figure 1B. syn. nov.

Trees or shrubs of up to $27 \mathrm{~m}$ in height, pubescent branches with rusty, glabrescent trichomes, usually without lenticels. Leaves alternate distichous to spiraled, 4-26 $\times 2-7 \mathrm{~cm}$, oblong, elliptic, oblanceolate or obovate, base cuneate, narrowly cuneate, obtuse or attenuated, rarely rounded, apex cuspid, acuminate, attenuate, emarginate, acute or obtuse, rarely mucronate, adaxial face glabrous, abaxial face glabrescent, trichomes rusty malpighiaceous along the main vein, whole, chartaceous to coriaceous, discolor; brochidodromous venation, main vein grooved on the adaxial face and protruding on the abaxial face, closely parallel secondary veins with striated aspect, indistinguishable from tertiary veins and superior orders on both faces, intramarginal vein present; petioles $0.3-1.12 \mathrm{~cm}$ long, canaliculate, pubescent to glabrous, rusty trichomes. Fascicles 2-8 flowers, axillary or ramiflorous. Flowers unisexual or bisexual, pedicel 1-6 mm long, pubescent, trichomes malpighiaceous, rusty. Sepals 5, 0.8-4 × 1-3 mm long, ovate to suborbicular, apex cuneate to rounded, outer face pubescent, inner face with bristled trichomes, margin non-ciliated. Petals 5, tube 1-3 mm long, lobes $0.4-1 \mathrm{~mm}$ long, ovate to suborbicular, apex cuneate to rounded, 
Table 1. Diagnostic characters in the separation of M. compta and M. gardneriana, according to Pennington (1990), and our observations about the variations of these characters.

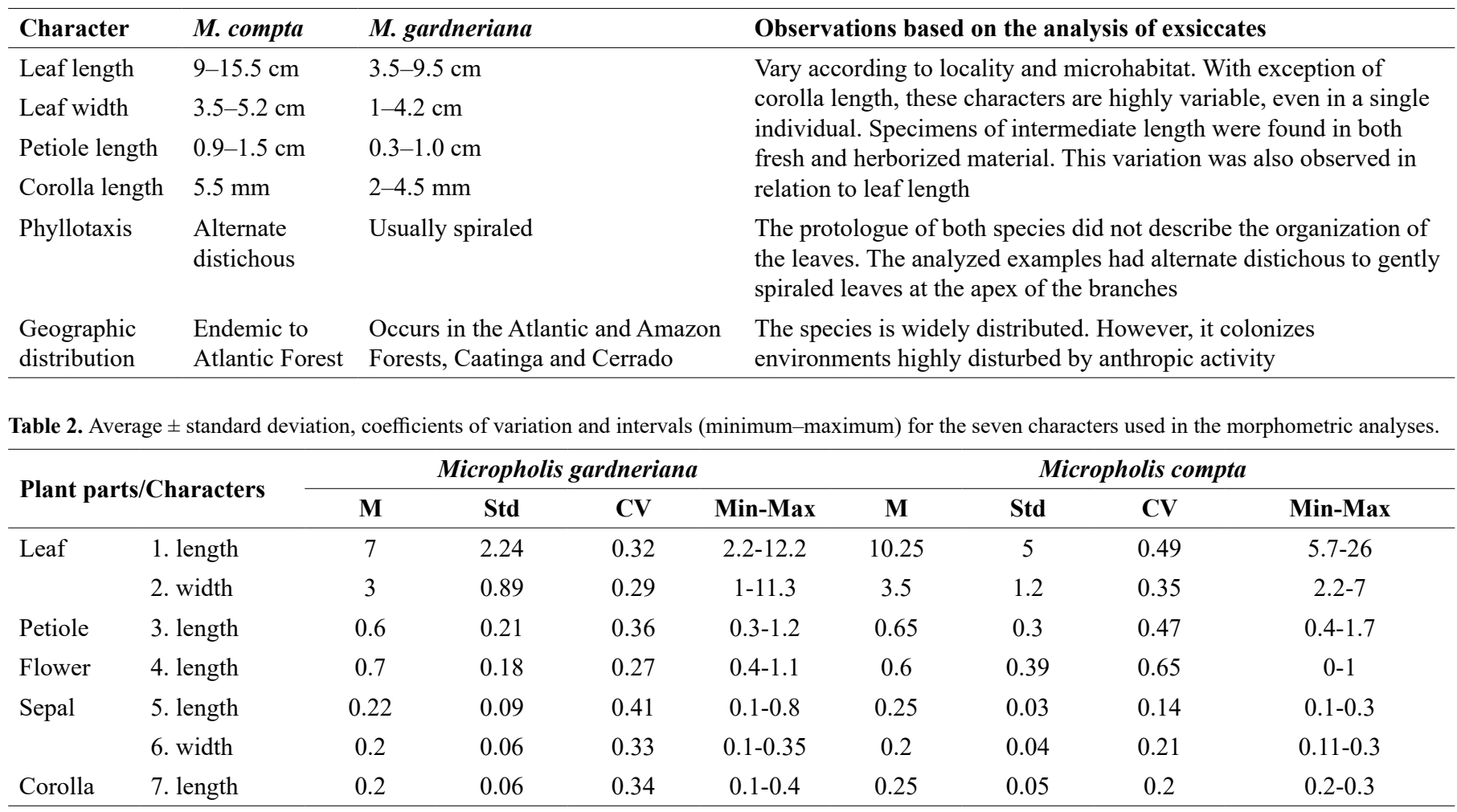

Table 3. Specimens of Micropholis (Sapotaceae) analyzed in relation to the anatomy of the petiole and the leaf blade.

\begin{tabular}{lll}
\hline Species & Voucher (Herbarium and registration) & Habitat \\
\hline M. gardneriana & BHCB 123798 & Semideciduous Seasonal Forest \\
& BHCB 17738 & Atlantic forest \\
& BHCB 43492 & Atlantic forest \\
& INPA 91085 & Cerrado \\
& INPA 136474 & Transitional vegetation between gallery forest and Cerrado \\
MBML 6923 & Atlantic Forest situated on slopes \\
\hline M. compta & ALCB 27284 & Atlantic Forest \\
& MBML 9837 & Atlantic Forest situated on slopes at altitude of $650-850 \mathrm{~m}$ \\
& UEC 170041 & Submontane Dense Ombrophylous Forest $450 \mathrm{~m}$ \\
& UEC 174840 & Atlantic Forest situated on slopes at altitude of $120 \mathrm{~m}$ \\
& PEUFR 42055 & Ombrophilous Dense Lowland Forest \\
\hline
\end{tabular}

glabrous. Stamens 5, included, 0.2-0.5 mm long, anthers $0.7-0.8 \mathrm{~mm}$ long, glabrous; vestigial stamens on female flowers; staminodes 5, 1-1.2 $\mathrm{mm}$ long, lanceolate, subulate or petaloid, glabrous. Disc present or absent. Ovary 5-locular, 1.8-3 mm long, ovoid to triangular, densely pubescent, trichomes rusty, golden, forming an arch at the base of the ovary or covering up to $2 / 3$ of the stylet; stylet $1-2 \mathrm{~mm}$ long, glabrous; simple stigma, slightly lobed to 5-lobed. Fruits $1-1.7 \times 0.6-2 \mathrm{~cm}$ long, ovoid to ellipsoid, glabrescent; residual trichomes at apex and base, with apiculus, persistent calyx, brown to blackish. Seed 0.6-1.4 cm long, laterally compressed ellipsoid, with smooth, glossy and rigid tegument, chestnut to brown; linear ventral scar extending along the length of the seed $1.1 \times 1.94 \mathrm{~cm}$ long, whitish to beige, matte.
Material examined: BRAZIL. Bahia: Entre Rios, RPPN Lontra Saudade, 31/V/1998, M.R. Fonseca et al. 0537 (INPA). Espírito Santo: Santa Teresa, Estação Biológica de Santa Lúcia, margem direita do Rio Timbuí, 8/X/1990, S.V. Pereira \& S.R. Cardoso s/n (MBML); Santa Teresa, Estação Biológica de Santa Lúcia, mata Atlântica de Encosta, 13/ IV/1993, L.D. Thomaz 919 (MBML); Santa Teresa, mata do Banestes, 16/VIII/2004, L. Kollmann \& W. Pizziolo 6941 (MBML); Linhares, Reserva Natural Vale, mata de Tabuleiro, 6/IV/1994, D.A. Folli 2274 (CVRD); 20/I/1994, D.A. Folli 2184 (CVDR). Goiás: Caldas Novas, mata de Galeria, 18/XI/1993, G.P. da Silva et al. s/n (CEN); Luziânia, fazenda corumbá, margem direita do Rio Corumbá, área de mata ciliar, 9/VI/2003, G. Pereira-Silva et al. 77789 (CEN); Silvânia, mata 

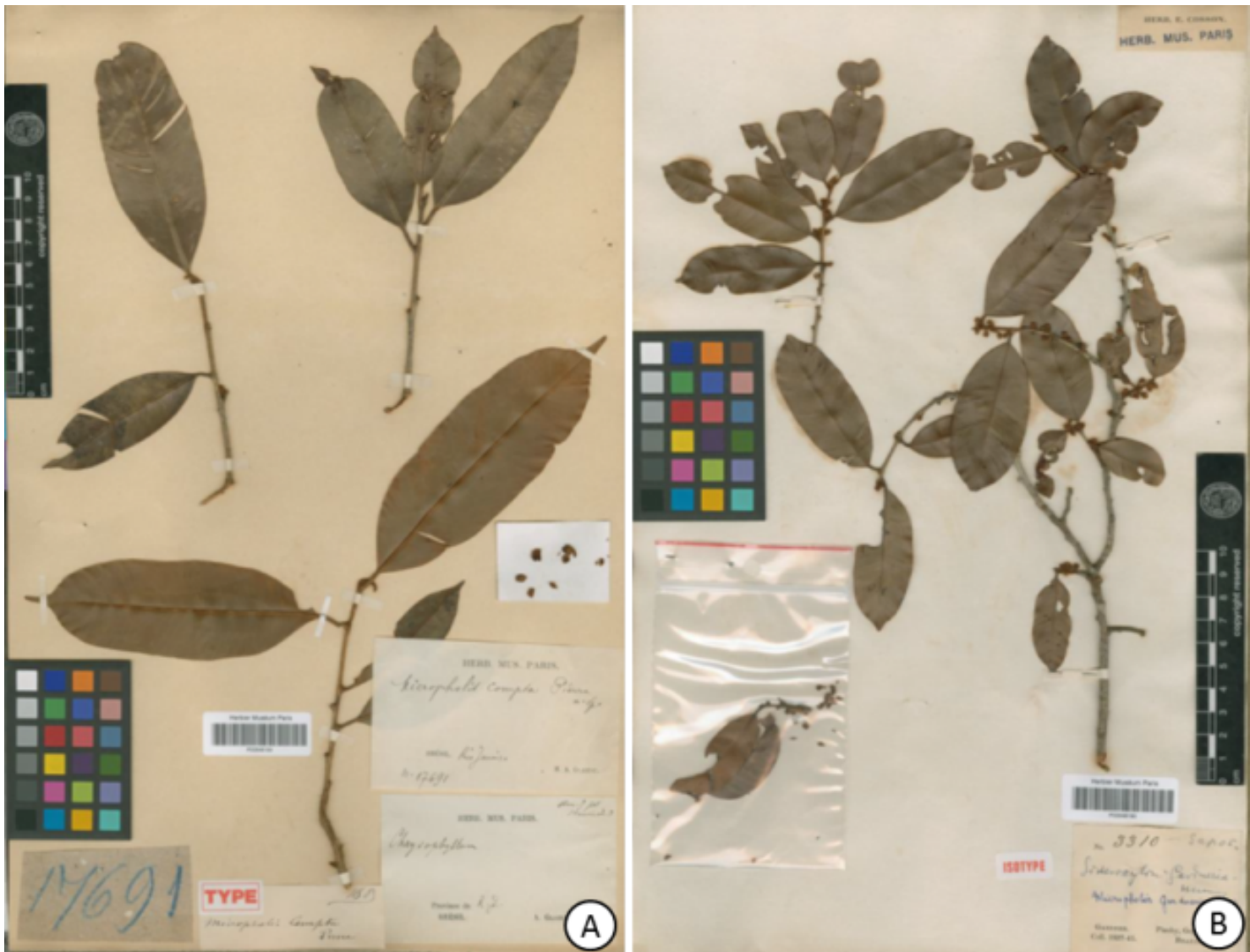

Figure 1. Type specimens (A) Holotype of Micropholis compta Pierre (P) e (B) Isotype of M. gardneriana (A. DC.) Pierre (P).

de Galeria, 2/VI/2003, G. Pereira-Silva et al. 7722 (CEN); Luziânia, floresta Estacional Semidecidual em estágio secundário, 9/XII/2007, C.H.G. Cezare et al. 428 (INPA). Goiás, $50 \mathrm{~km} \mathrm{~S}$ of Caiaponia, X/1838, W.J. Burchell 8244 (K). Goiás, IX/1839, G. Gardner 3310 (K). Maranhão: Estreito, Cerrado, 19/X/2005, G. Pereira-Silva et al. 10208 (CEN); Transamazônica à $35 \mathrm{~km}$ da cidade de Carolina, vegetação transicional entre mata de Galeria e Cerrado, 15/IV/1983, N.A. Rosa et al. 1101 (INPA). Minas Gerais: Caratinga, região de mata Atlântica, 20/I/1990, L.V. Costa et al. 404 (BHCB); Catas Altas, Serra do Caraça, mata de galeria, 16/XII/2000, R.C. Mota 1164 (BHCB); Barão de Cocais, floresta Estacional Semidecidual Montana 7/V/2008, S.G. Rezende et al. 2689 (BHCB); Marliéria, Parque Estadual do Rio Doce 8/VII/2004, G.S. França \& F. Raggi 605 (BHCB); Itambé do Mato Dentro, Distrito de Santana do Rio, APA do Parque Nacional da Serra do Cipó, 16/III/2008, M.F. Santos \& H. Serafim 319 (BHCB). Pernambuco: Recife, mata de Dois Irmãos, 17/II/1990, M.L. Guedes 2289, (ALCB); Igarassu, mata da Usina São José, floresta Ombrófila Densa das Terras Baixas, H.C.H. Silva 197 (PEUFR); H.C.H. Silva et al. 168 (PEUFR). Rio de Janeiro: Rio das Ostras, Reserva Biológica União, região de Morro, 27/VIII/1998, P.P. de Oliveira 4111 (BHCB); Rio de Janeiro, 13/V/1975, A. Glaziou 8224 (K). Rondônia: Pimenta Bueno, estrada do rio Pimenta Bueno km 11, 8/XI/1979, M.G.G. Vieira et al. 1029 (INPA); 10/XI/1979, M.G.G. Vieira et al. 1061 (INPA); Vilhena, $85 \mathrm{~km}$ from Vilhena toward Guaporé on BR 364, 9/XI/1979, B.W. Nelson et al. 394 (INPA). São Paulo: Ubatuba, Picinguaba, mata
Atlântica de Encosta, 12/I/1997, M. Sanchez \& F. Pedroni 740 (UEC); Ubatuba, floresta Ombrófila Densa Submontana, VII/2006, A.L.C. Rochelle 856 (UEC). Sergipe: Santa Luzia do Itanhi, Castro, cerca de $2 \mathrm{~km}$ na estrada de Castro para Santa Luzia do Itanhi, mata costeira, Restinga arbórea intercalada com coqueiral, várzea e campos úmidos, 5/X/1993, A.M. de Carvalho et al. 4317 (ASE); Estância, povoado Fonte Nova, nascente um, 17/XII/2009, C. Calazans et al. 333 (ASE); Povoado Aguada Carmópolis, capoeira de mata subperenifolia, 15/ VI/1982, E. Carneiro 383 (ASE); Itaporanga D ‘Ajuda, fazenda trapsa, mata Atlântica, 21/VII/2009, J.P. Souza-Alves s/n (ASE); Itaporanga D 'Ajuda, 19/V/2014, F.B. Gonçalves 160 (ASE). Tocantins: Paranã, fazenda Petrolina, mata de Galeria, 13/IX/2003, A.C. Sevilha et al. 3549 (CEN); São Domingos, área de inundação da usina São Domingos, mata ciliar, 25/VI/2001, A.C. Sevilha 2061 (CEN).

Additional material examined: BOLIVIA. Velasco: Serrania de Huanchaca, Santa Cruz, Parque Nacional Noel Kempff M. Unos 5-7 $\mathrm{km}$ al sur del Rio Itenez o Guaporé $\sim 15 \mathrm{~km}$ al sureste del estancia Flor de Oro. Bosque enano sobre margen de la maseta, 13/VIII/1992, $M$. Toledo 68 (F). COLOMBIA. Vichada: Puerto Carreño, 23/X/ 1938, J. Cuatrecasas 3984 (F). VENEZUELA. Guarico: 6 km from Estacíon Biologica Calabozo, XII/1965, L, Aristeguieta 5939 (US). GUIANA. U. Takatu-U. Essequibo: Acarai Mts; Sipu River 8-10 km from juncture with Essequibo River, 12/III/1994, T.W. Henkel et al. 5123 (US). PERU. Las Piedras, Reserva Amazónica, Trocha G, 8/IV/2004, L. Valenzuela et al. 3340 (MO). 


\section{Distribution and habitat}

Brazil (BA, DF, ES, GO, MA, MG, MT, PA, PE, RJ, RO and SE), Colombia and Venezuela (Figure 2). With the inclusion of M. compta in the circumscription of M. gardneriana, and based on recent collections and further study of the herbarium material, the geographic distribution of the species was widened in Brazil, with new records for the states of Amazonas, Mato Grosso do Sul and São Paulo. Additionally, the species was reported for the first time in Bolivia, Guyana, and Peru, expanding its distribution in South America (Figure 2). In Brazil, the species occurs in a wide variety of habitats, including dry areas with strongly seasonal climate, gallery forest, transitional vegetation between gallery forest and Cerrado (sensu lato), rocky environments, Caatinga (sensu stricto), evergreen forests in Amazon, Atlantic forest, in forests of restinga and tabuleiro, and occasionally in montane forest (Figure 2).

\section{Phenology}

Flowers from February to December and produces fruit in MarchApril and October-December.

\section{Conservation status}

M. gardneriana s.l presents a wide distribution, extending evenly through large expanses of South America (Fig. 2). In a case of formal assessment, the species would possibly be categorized as least concern (LC), owing to an EOO of 8,589,669,704 $\mathrm{km}^{2}$, and as endangered, due to an AOO of $380,000 \mathrm{~km}^{2}$ (IUCN 2001). This species occurs within some legally designated conservation units, throughout their entire area or in small fragments, encompassing a wide area of occurrence, as its AOO value reflects.

\section{Anatomic notes}

M. gardneriana and $M$. compta are closely related in their leaf anatomy (compare Figure 3A-C with Figure 3D-F). The petiole presents a concave-convex contour in the cross section (Figure 3A and 3D). The epidermis is covered by a thin cuticle, and malpighiaceous unicellular trichomes of the $\mathrm{T}$ type are visible (Figure 3A and 3D). The epidermal cells are isodiametric, quadrangular and have thickened walls. The external periclinal wall presents U-shaped secondary thickening. The cortex is formed by external angular collenchyma and by internal filling of parenchyma (Figure 3B and 3E). The vascular system has a concave-convex shape, formed by a collateral bundle of greater diameter. Two to four accessory collateral bundles are arranged adaxially on each side of the main vascular bundle (Figure 3A-B and 3D-E). Idioblasts containing prismatic monocrystals occur in cells of the collenchyma and of the cortical (Figure 4A) and medullary parenchyma (Figure 4B). Laticifers occur in association with the vascular tissue and the cortical and medullary parenchyma.

The leaves are bifacial. The epidermis is unistratified on the adaxial and abaxial surfaces, the cells are isodiametric, quadrangular and rectangular, with straight anticlinal walls covered with a smooth, thin cuticle, presenting $\mathrm{U}$-shaped thickening on the abaxial surface of the principal vein, where the external periclinal wall is thickest (Figure 3A-F and Figure 4C). Subjacent to the adaxial epidermis sits a layer of

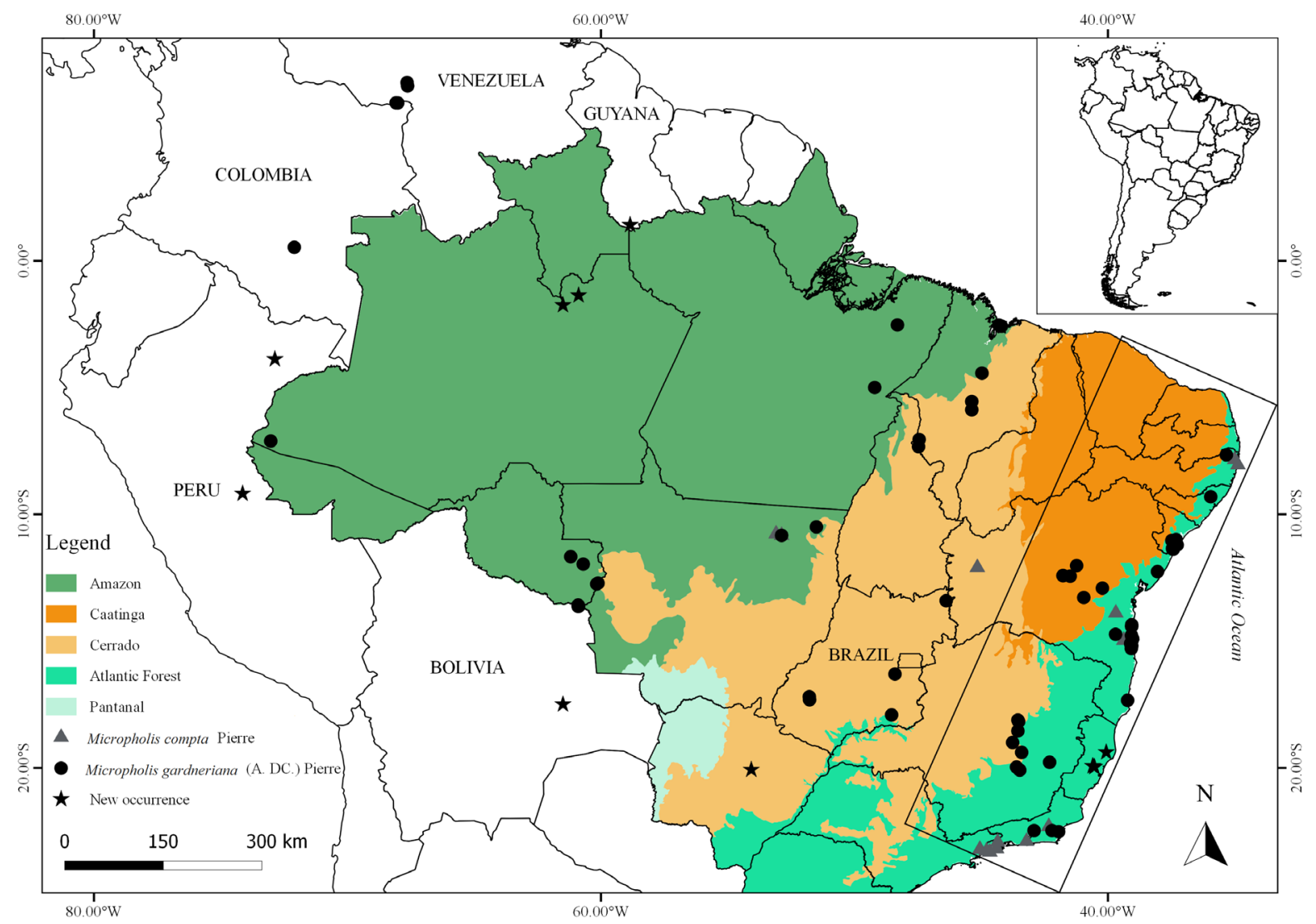

Figure 2. Map indicating the distribution of Micropholis gardneriana s.l in South America. 

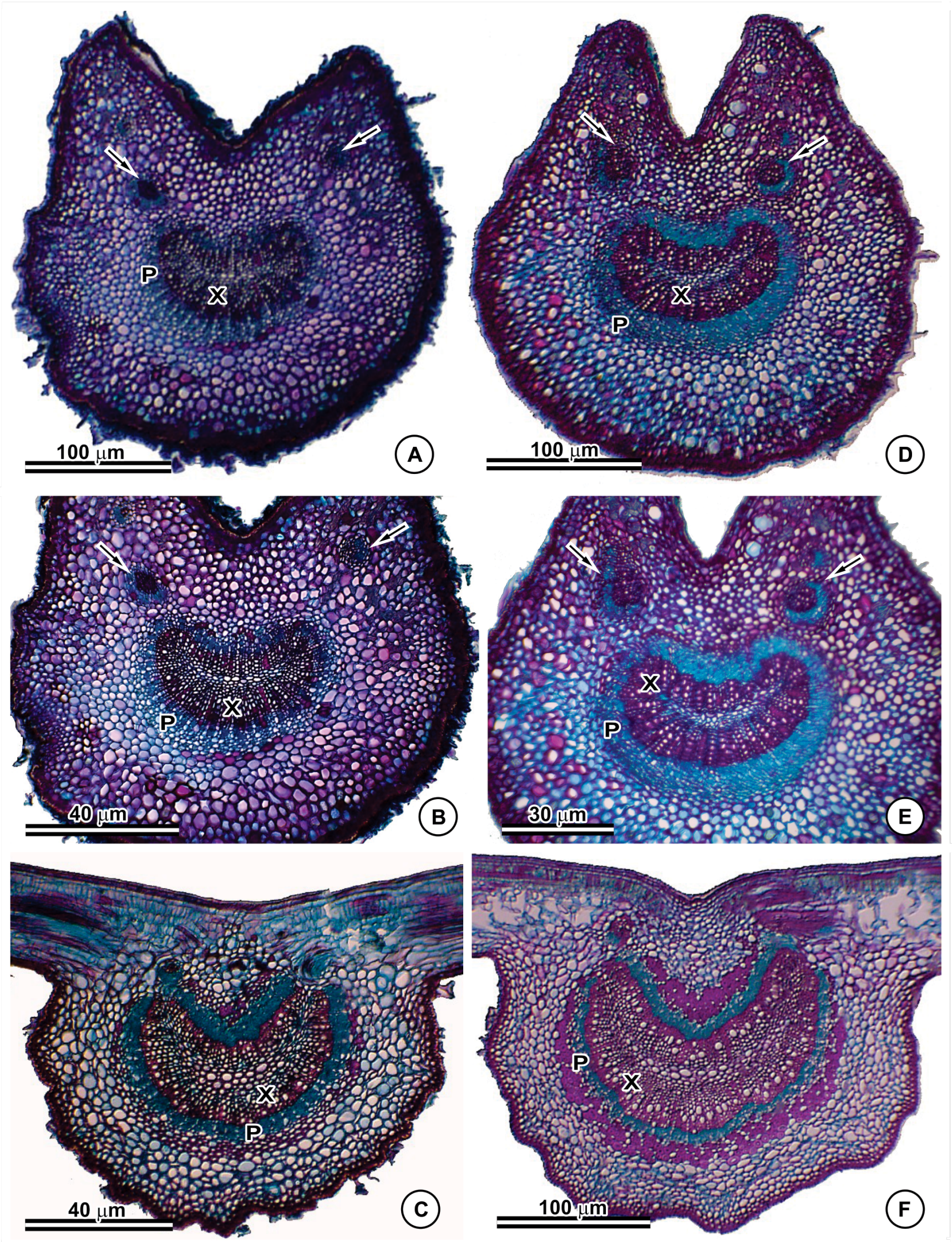

Figure 3. Leaf anatomy of Micropholis gardneriana (left column) and Micropholis compta (right column) in transversal sections. A-D. overview of the petiole with accessory bundles (arrows); $\mathrm{E}$ and $\mathrm{F}$. overview of the midrib. $C=$ idioblasts containing prismatic monocrystals, $P=$ phloem, $X=\mathrm{xylem}$. 

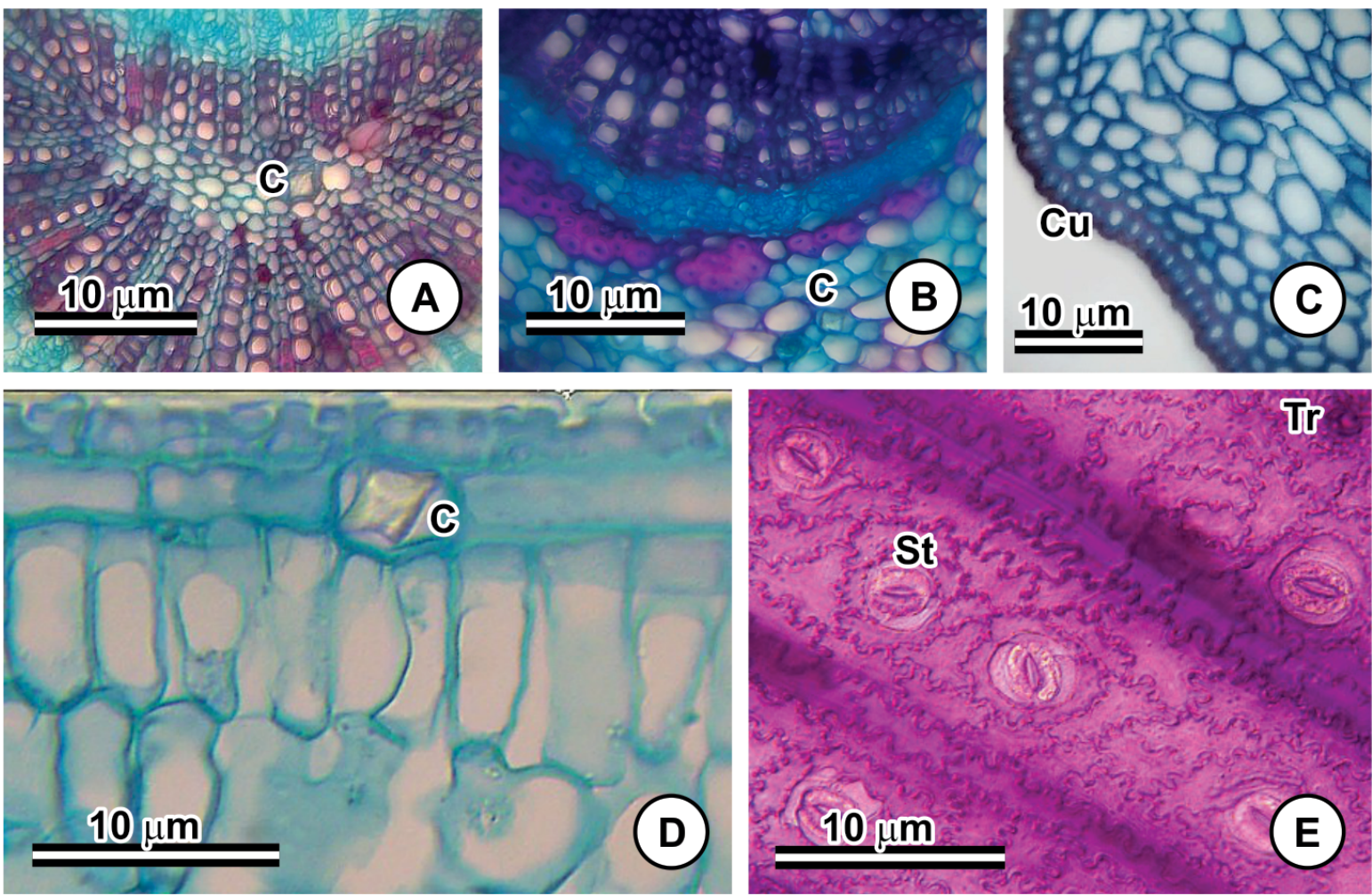

Figure 4. Leaf anatomy of Micropholis gardneriana sl. in transverse and paradermic sections. A. detail of the prismatic monocrystals in parenchyma medular of the petiole; B. detail of the prismatic monocrystals in parenchyma cortical of the midrib; C. detail of U-shaped cuticle that is thicker on the abaxial side of the midrib; B. detail of the mesophyll, palisade parenchyma, prismatic monocrystals and subepidermal layer; $\mathbf{C}$. detail of the anisocytic stomas and scars left by trichomes; $C=$ idioblasts containing prismatic monocrystals, $C u=$ cuticle, $S t=$ stomas, $T r=$ scars left by trichomes.

periclinally elongated achlorophyllous cells of unknown origin (Figure 4D). The leaf lamina is hypostomatic, with anisocytic stomas situated on the same level as the ordinary epidermal cells (Figure 4E).

The mesophyll is dorsiventral (Figure 3C and 3F). The palisade parenchyma is composed of two noncontinuous layers of elongated anticlinal cells, while the other layers of the mesophyll constitute the lacunar parenchyma (Figure 4D). Unicellular T-shaped malpighiaceous trichomes occur sparsely on the abaxial surface of the mesophyll, concentrated in the midrib (Figure $3 \mathrm{C}$ and $3 \mathrm{~F}$ ). Sclereids, laticifers and idioblasts containing prismatic monocrystals occur in the mesophyll (Figure 4D). In cross section, occurs angular collenchyma adaxially and abaxially in the midrib (Figure $3 \mathrm{C}$ and $3 \mathrm{~F}$ ). The contour of the midrib varies from flat to concave-convex (Figure $3 \mathrm{C}$ and $3 \mathrm{~F}$ ). The vascular system is concave-convex, formed by a single collateral bundle enveloped by a sclerenchymatous sheath (Figure 3C and 3F). Laticifers occur, preferentially, in the parenchyma intercalated in the vascular bundle. Idioblasts containing prismatic monocrystals occur in the cells of the cortical parenchyma (Figure 4B).

\section{Discussion}

Morphological and anatomical attributes of $M$. compta and M. gardneriana overlap in all of the examined samples (Figure 1 and 2). Variations in the length of the leaf, petiole and corolla were the quantitative attributes mentioned by Pennington (1990) in the distinction between the two species (Table 1). These characteristics were observed in the present study; however, the descriptive statistics suggest that the separation of the two species is not supported by these characters, indicating that these taxa form a morphological continuum (Table 2).

Mapping all the specimens showed that the geographic distributions of these species overlaps in the Atlantic and Amazon Forests and the Cerrado (Figure 2). Furthermore, the two analyzed taxa are characterized by their presentation of oblong, elliptical, oblanceolate or obovate leaves. This variation occurs within the same individual and may be related to the different environmental conditions of the habitats colonized by M. gardneriana l.s, since some of the species can occupy a wide ecological niche, exhibiting high phenotypic plasticity (Bunger et al. 2015; Ribeiro et al. 2018).

Leaf anatomical characters, including epidermal attributes (Metcalfe \& Chalk 1979; Dickison 2000, Ospina 2016), may support taxonomic delimitation at different hierarchical levels (Solereder 1908; Metcalfe \& Chalk 1950a, 1979b; Monteiro et al. 2007; Coutinho et al. 2016). In cross section, the leaves of all examined specimens have a distinguishable subepidermal layer on the adaxial surface (hypodermis), with periclinally elongated cells, and the epidermis of the abaxial surface presents U-shaped thickening in the region of the principal vein.

The number of strata of the palisade parenchyma may vary in response to environmental conditions (Eames \& Mac Daniels 1945; Metcalfe \& Chalk 1983). Independent of where they were collected, however, all examined specimens have two noncontinuous strata of 
palisade parenchyma. This characteristic was considered relevant by Monteiro et al. (2007) for the delimitation of species belonging to Pouteria Aubl. of the Southeast region of Brazil.

In cross section, the contour of the principal vein can vary from flat to concave-convex, but the shape of the vascular system is always concave-convex, with a collateral vascular bundle enveloped by a sheath of sclerenchymatous cells. The petiole, in cross section, presents the contour and shape of the concave-convex vascular system. Two to three conspicuous accessory bundles are visible. The specimens attributed to $M$. compta exhibit the same pattern of anatomical characters, which supports the synonymization of the species.

In contrast, the salient characteristics of several genera of Sapotaceae, including Pouteria Aubl. Monteiro et al. (2007), Manilkara Adans. Almeida Jr. et al. (2012), and Diploon Cronquist Lima et al. (2019), are the occurrence of prismatic monocrystals; anisocytic stomas restricted to the abaxial surface of the leaf; the occurrence of malpighiaceous T-shaped trichomes, most dense in the region of the principal vein; articulated laticifers; and the dorsiventral organization of the mesophyll. These attributes were also observed in all of the examined specimens and must therefore be used with caution in the distinction between the taxa.

Our results showed that the anatomical and morphological attributes compared between all the analyzed specimens confirm that all the assessed characteristics, including those cited by Pennington (1990) as diagnostic for the separation of M. compta and M. gardneriana, overlap considerably, meaning that they are included within the same pattern of variation. Therefore, we propose $M$. compta as a new synonymy under M. gardneriana.

\section{Acknowledgements}

We thank the Laboratório de Florística de Ecossistemas Costeiros (UFRPE) for providing the necessary infrastructure for the study, and the Laboratórios de Biologia Vegetal (UESPI) and Laboratório de Estudos Botânicos (UFMA) for the technical support in anatomical and taxonomical analyses, respectively. This study was financed in part by the Coordenação de Aperfeiçoamento de Pessoal de Nível Superior Brasil (CAPES) - Finance Code 001, and by Auxílio à Mobilidade Discente (AMD-0190-2.00/16), provided by Fundação de Amparo a Ciência e Tecnologia do Estado de Pernambuco.

\section{Author Contributions}

Angélica Cândida Ferreira: Substantial contribution in the concept and designer of the study; Contribution to data collection; Contribution to manuscript preparation; Contribution to critical revision adding intellectual content.

Carmen Silvia Zickel: Substantial contribution in the concept and designer of the study; Contribution to data collection; Contribution to manuscript preparation; Contribution to critical revision adding intellectual content.

Josiane Silva Araújo: Contribution to data collection; Contribution to manuscript preparation; Contribution to critical revision adding intellectual content.

Eduardo Bezerra de Almeida Jr: Contribution to manuscript preparation; Contribution to critical revision adding intellectual content.

\section{Conflicts of interest}

The authors declare that they have no conflict of interest related to the publication of this manuscript.

\section{References}

ALMEIDA Jr, E.B., ARAÚJO, J.S., SANTOS-FILHO, F.S., ZICKEL, C.S. 2012. Leaf morphology and anatomy of Manilkara Adans. (Sapotaceae) from Northeastern Brazil. Plant Systematic and. Evolution 299: 1-9.

BACHMAN, S., MOAT, J., HILL, A.W., TORRE, J., SCOTT B. 2011. Supporting redlist threat assessments with GeoCAT: geospatial conservation assessment tool. ZooKeys 150: 117-126.

BEENTJE, H. 2016. The Kew Plant Glossary: an illustrated dictionary of plant terms. 2nd. edn. Londres, Royal Botanic Gardens.

BUNGER, M.O., EINSEHLOR, P., FIGUEIREDO, M.L.N., STEHMANN, J.R. 2015. Resolving species delimitations in the Eugenia involucrata Group (Eugenia sect. Phyllocalyx - Myrtaceae) with morphometric analysis. Systematic Botany 40: 995-1002.

BRAZILIAN FLORA, 2020. under construction. Micropholis. Jardim Botânico do Rio de Janeiro. http://servicos.jbrj.gov.br/flora/search/Micropholis. Acceced on 15 January 2018.

COUTINHO, I.A.C., RANDO, J.G., CONCEIÇÃO, A.S., MEIRA, R.M.S.A. 2016. A study of the morphoanatomical characters of the leaves of Chamaecrista (L.) Moench sect. Apoucouita (LegunimosaeCaesalpinioideae). Acta Botanica Brasilica 2: 205-221.

CRUZ, E.D., CARVALHO, J.E.U. 2003. Biometria de frutos e sementes e germinação de curupixá (Micropholis cf. venulosa Mart. \& Eichler Sapotaceae). Acta Amazonica 3: 389-398.

DICKINSON, W.C. 2000. Integrative plant anatomy. San Diego, Academic Press.

EAMES, A.J., MAC DANIELS, L.H. 1945. An introduction to plant anatomy. New York, McGraw- Hill Book Company.

HOWARD, R.A. 1979. The petiole. In: Metcalfe CR, Chalk L (eds) Anatomy of the dicotyledons: systematic anatomy of the leaf and stem. Oxford, Oxford Claredon.

IUCN - International Union for Conservation of Nature. 2017. Guidelines for using the IUCN red list categories and criteria, version 13. http://www. iucnredlist.org/documents/RedListGuidelines.pdf. 23 Fev. 2019.

ITHAKA. 2019. JSTOR Global Plants. https://plants.jstor.org/. Acceced on 12 January 2019.

KRAUS, J.E., ARDUIN, M. 1997. Manual básico de métodos em morfologia vegetal. Rio de Janeiro, Editora da Universidade Federal Rural do Rio de Janeiro.

LANDRUM, L.R. 1986. Campomanesia, Pimenta, Blepharocalyx, Legrandia, Acca, Myrrhinium and Luma. Flora Neotropica 45: 1-178.

LIMA, R.G.V.L., LIMA, L.F., FERREIRA, A.C., ARAÚJO, J.S., ZICKEL, C.S. 2019. Leaf morphoanatomy of Diploon Cronquist (Sapotaceae Juss.). Biotaneotropica 1: 1-7.

METCALFE, C.R., CHALK, L. 1950a. Anatomy of dicotyledons: leaves, stem, and wood in relation to taxonomy with notes on economic uses. Oxford, Clarendon Press.

METCALFE, C.R., CHALK, L. 1979b. Anatomy of the dicotyledons: systematic anatomy of the leaf and stem. Oxford, Claredon Press.

METCALFE, C.R., CHALK, L. 1983. Anatomy of the Dicotyledons. Volume II: Wood Structure and Conclusion of the General Introduction. 2nd. edn. Oxford, Science Publications.

MONTEIRO, M.H.D.A., NEVES, L.J., ANDREATA, R.H.P. 2007. Taxonomia e anatomia das espécies de Pouteria Aublet (Sapotaceae) do estado do Rio de Janeiro, Brasil. Pesquisas Botânica 58: 7-118.

OSPINA, J.C. 2016. New lectotypifications and new synonyms in Festuca (Poaceae, Pooideae, Loliinae) from the Central Andes. Phytotaxa 4: 247-258.

PENNINGTON, T.D. 1991. The genera of Sapotaceae. Royal Botanical Garden, Kew. 
PENNINGTON, T.D. 2006. Flora da Reserva Ducke, Amazonas, Brasil: Sapotaceae. Rodriguésia 57: 251-366.

PIERRE, J.B.L. 1904. Sapotaceae. In: Urban, I, Symbolae Antillanae seu Fundamenta Florae Indiae Occidentalis. Lipsiae 5: 95-176.

Quantum GIS Development Team. 2012. Quantum GIS Geographic Information System. Open Source Geospatial Foundation Project. http://qgis.osgeo.org/.

RAABE, J., MENEZZI, C.D., GONÇALEZ, J. 2017. Avaliação da superfície de lâminas decorativas de curupixá (Micropholis venulosa Mart. Eichler). Floresta e Ambiente 24: 1-8.

REIS, L.P., SILVA, J.N.M., REIS, P.C.M., CARVALHO, J.O.P., QUEIROZ, W.T., RUSCHEL, A.R. 2013. Efeito da exploração de impacto reduzido em algumas espécies de Sapotaceae no leste da Amazônia. Floresta 3: 395-406.

RIBEIRO, R.T.M., LINSINGEN, L.V., CERVI, A.C., SILVA, N.M.F., LOIOLA, M.I.B., SALES, M.F. 2018. New synonyms and recircumscription of Terminalia sect. Diptera (Combretaceae) from South America. Systematic Botany 1: 250-257.
SMITH, F.H., SMITH, E.C. 1942. Anatomy of the inferior ovary of Darbya. American Journal of Botany 6: 464-471.

SOLEREDER, H. 1908. Systematic Anatomy of the Dicotyledons. Oxford, Clarendon Press.

SOUZA, O.W., ALVES-ARAÚJO, A. 2017. Flora do Espírito Santo: Micropholis (Sapotaceae-Chrysophylloideae). Rodriguésia 5: 1871-1882.

SWENSON, U., ANDERBERG, A.A. 2005. Phylogeny, character evolution, and classification of Sapotaceae (Ericales). Cladistics 2:101-130.

TERRA-ARAUJO, M.H., FARIA, A.D., RIBEIRO, J.E.L.S., SWENSON, U. 2012. Flower biology and subspecies concepts in Micropholis guyanensis (Sapotaceae): evidence of ephemeral flowers in the family. Australian Systematic Botany 25: 295-303.

THEOBALD, W.L., KRAHULIK, J.L., ROLLINS, R.C. 1979. Trichome description and classification. In: Metcalfe CR, Chalk L. (eds) Anatomy of the dicotyledons: systematic anatomy of the leaf, stem. 2nd edn. Oxford, Oxford Claredon.

THIERS, B. [continuously updated]. 2019. Index Herbariorum: a global directory of public herbaria and associated staff. New York, New York Botanical Garden's Virtual Herbarium. http://sweetgum.nybg.org/science/ih/. Acceced on 01 March 2019 